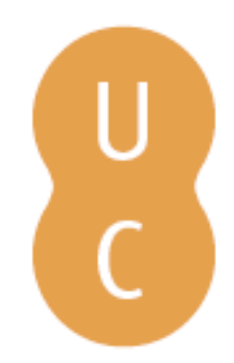

\title{
nommalina
}

\section{As «sombras» da Claridade: entre o discurso de integração regional e a retórica nacionalista}

\author{
Autor(es): $\quad$ Barros, Víctor \\ Publicado por: Imprensa da Universidade de Coimbra \\ URL \\ persistente: URI:http://hdl.handle.net/10316.2/32165 \\ DOI: $\quad$ DOI:http://dx.doi.org/10.14195/978-989-26-0339-1_15 \\ Accessed : $\quad$ 26-Apr-2023 13:23:40
}

A navegação consulta e descarregamento dos títulos inseridos nas Bibliotecas Digitais UC Digitalis, UC Pombalina e UC Impactum, pressupõem a aceitação plena e sem reservas dos Termos e Condições de Uso destas Bibliotecas Digitais, disponíveis em https://digitalis.uc.pt/pt-pt/termos.

Conforme exposto nos referidos Termos e Condições de Uso, o descarregamento de títulos de acesso restrito requer uma licença válida de autorização devendo o utilizador aceder ao(s) documento(s) a partir de um endereço de IP da instituição detentora da supramencionada licença.

Ao utilizador é apenas permitido o descarregamento para uso pessoal, pelo que o emprego do(s) título(s) descarregado(s) para outro fim, designadamente comercial, carece de autorização do respetivo autor ou editor da obra.

Na medida em que todas as obras da UC Digitalis se encontram protegidas pelo Código do Direito de Autor e Direitos Conexos e demais legislação aplicável, toda a cópia, parcial ou total, deste documento, nos casos em que é legalmente admitida, deverá conter ou fazer-se acompanhar por este aviso.

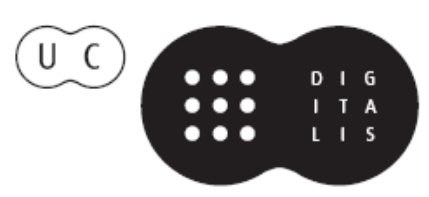




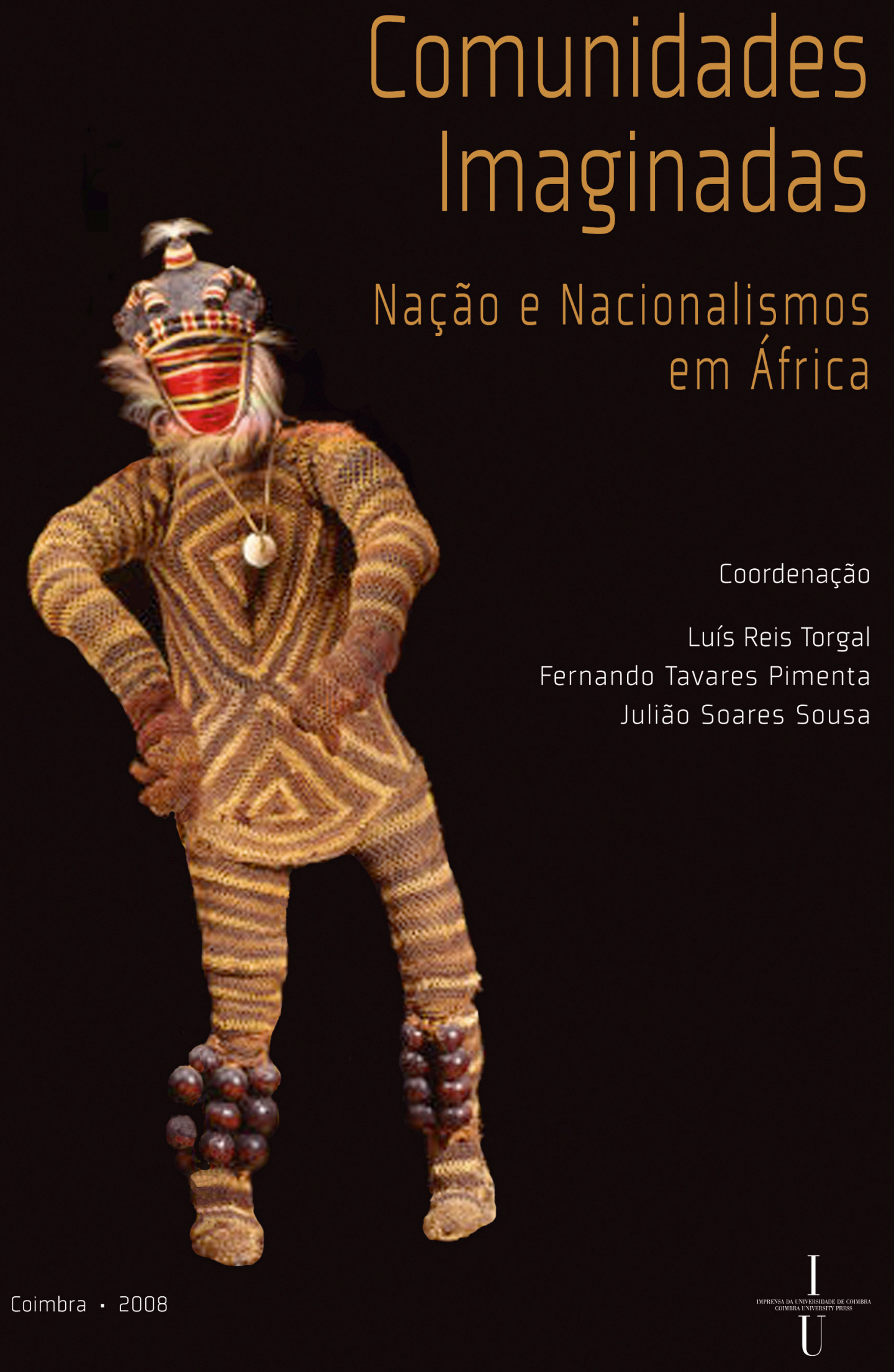




\title{
Comunidades Imaginadas \\ Nação e Nacionalismos em África
}

\author{
Coordenação \\ Luís Reis Torgal \\ Fernando Tavares Pimenta \\ Julião Soares Sousa
}

Coimbra $\cdot 2008$

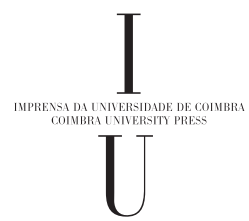




\begin{abstract}
COORDENAÇÃO EDITORIAL
Imprensa da Universidade de Coimbra

Email: imprensauc@ci.uc.pt

URL: http://www.uc.pt/imprensa_uc
\end{abstract}

CONCEPÇÃO GRÁFICA

António Barros

PAGINACÁO

Paulo Oliveira

[PMP]

EXECUÇÃO GRÁFICA

?????????????

ISBN

978-989-8074-57-7

DEPÓSITO LEGAL

????????????????????????

OBRA PUBLICADA COM A COLABORAÇÃO DE:

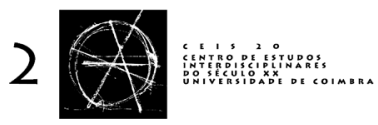

OBRA PUBLICADA COM O APOIO DE:

FCT Fundação para a Ciência e a Tecnologia

MINISTÉRIO DA CIÊNCIA, TECNOLOGIA E ENSINO SUPERIOR Portugal

Apoio do Programa Operacional Ciência, Tecnologia, Inovação do Quadro Comunitário de Apoio III 



\title{
Víctor Barros
}

\author{
AS «SOMBRAS» DA CLARIDADE \\ ENTRE O DISCURSO DE INTEGRAÇÃO REGIONAL E A RETÓRICA NACIONALISTA
}

O objectivo central deste trabalho consiste, primeiramente, numa pretensão analítica quanto à possibilidade de discernir sobre a clareza do projecto literário Claridade enquanto forma de manifestação de um discurso identitário de e para Cabo Verde. É de referir que estamos perante um tipo de abordagem em que os intelectuais constituem e representam a voz activa na elaboração de discursos, de linguagens e de determinados paradigmas, para a formataçáo da ideia de comunidade que se pretende imaginar. Nesta perspectiva reconhecemos atribuir aos intelectuais - neste caso personificados no projecto literário Claridade - um papel determinante na elaboração e definição de elementos ajustados ao quadro da comunidade cultural específica em nome da qual se pronunciaram. Estas consideraçôes servem de suporte propedêutico para reflectirmos em torno da problemática hermenêutica do debate sobre quem pensa, quem formata e quem imagina e veicula a ideia de comunidade imaginada. A ideia de comunidade imaginada encerra em si o exercício da imaginação, na medida em que ela é também imaginada e representada (antes) por aqueles que dedicam ao exercício de nos convocar a imaginá-la enquanto totalidade homogénea. Sendo assim, a comunidade imaginada é-nos dada a imaginar através das representaçôes (simbólicas e materiais) e dos discursos elaborados por aqueles que pronunciam os termos da sua definiçáo.

Sendo assim, pensamos ser pertinente propor uma reflexão sobre a forma como a ideia de pertença de Cabo Verde no quadro da colonização portuguesa ficou patenteada em alguns textos de carácter mais ensaísticos dados à estapa na Claridade, de modo a podermos perceber os pressupostos enunciadores da justificação identitária. Por exemplo, sobre esta questão, João Lopes proferiu que "o facto positivo é a criação em Cabo Verde de um ambiente de grande liberdade humana, nascida desse processus sui generis absolutamente portuguez..." . Ou ainda, na forma como Manuel Lopes considerou que "é vulgar verem-se desembarcar nestas ilhas africanas, principalmente em S. Vicente, estrangeiros sedentos de exotismos, com aquela doentia curiosidade de quem pisa terras de África e, por conseguinte, terras de mistério, e que ao cabo de meia hora de cirandagem, tornam a embarcar desiludidos e azedos, porque nada de

\footnotetext{
${ }^{1}$ João Lopes, “Apontamento", Claridade, no 1, São Vicente, Cabo Verde, Março de 1936, p. 9.
} 
novo colheram, nenhum mistério desvendaram: não viram manipansos, não assistiram sequer a uma sessão de magia negra. O problema do caboverdiano é menos de ordem tradicional e estático, que cultural e dinâmico"2.

Estes posicionamentos asseguram e corroboram a nossa problemática teóricoanalítica fundamental: a afirmação e legitimação das teses de Claridade dependiam da justificação e da argumentação teórica em relação ao maior ou menor grau de presença e permanência de traços e elementos africanos e/ou europeus no quadro da representaçáo e da concepçấo da particularidade ou singularidade da cultura caboverdiana. Singularidade entendida e concebida numa lógica regional e provinciana no quadro do mundo português do além-mar, desterritorializado, que Portugal criou, tal como ficou patente no seguinte enunciado: "com gente escura criou-se, na verdade, em pleno Trópico, mais uma província de Portugal" ${ }^{3}$. Esta perspectiva é elucidativa quanto ao modo como a Claridade, através dos seus intelectuais, projectou, elaborou e veiculou o jogo discursivo da identidade caboverdiana no contexto da intersecçáo civilizacional do arquipélago entre a África e a Europa.

Feitas estas consideraçóes podemos afirmar que com este texto pretendemos demonstrar as possibilidades potenciais ou reais da Claridade ser ou não uma forma de manifestação de uma consciência nacionalista, tendo em conta a defesa de uma suposta identidade regional, tributária da cristalização da mestiçagem e estribada na ideia de uma harmoniosa síntese étnico-cultural. Partindo do pressuposto de uma suposta defesa da caboverdianidade, podemos ser tentados a ancorar a Claridade nos termos do nacionalismo. Ou seja, à partida podemos facilmente ser induzidos a pensar que estamos perante a manifestação de um nacionalismo ou de uma consciência nacionalista, principalmente se centrarmos exclusivamente no trabalho de mediaçáo cultural de Cabo Verde no quadro da colonização portuguesa levado a cabo pelos intelectuais da Claridade. Porém, não podemos esquecer que o nacionalismo não se reduz exclusivamente a ser um movimento. É também uma ideologia, uma doutrina, uma linguagem, um sentimento. Do ponto de vista do nacionalismo pensamos que a Claridade se afasta consideravelmente da ideia de movimento, doutrina ou ideologia nacionalista, podendo parecer aproximar-se ao nacionalismo enquanto linguagem ou sentimento em termos de conteúdos e substância, dada à problemática literária da insularidade, da evasão, da seca, do mar, do drama do homem ilhéu, etc. Nacionalismo enquanto linguagem, sobretudo se pensarmos na forma como o discurso escrito era articulado em relação aos elementos constituintes da comunidade insular arquipelágica (as tradiçôes culturais) e também se pensarmos que o primeiro número da revista ostenta na capa inscriçóes em crioulo. No entanto, nos números subsequentes, todas essas tradiçôes foram assumidas claramente como sendo adaptaçôes de motivos europeus. Por esta razão, quando manuseamos conceptualmente o nacionalismo, somos levados a questionar o sentido da linguagem e dos discursos veiculados, tendo em atençáo os possíveis deslizes hermenêuticos que a ideia de um suposto nacionalismo poderá operar face ao exercício de exumação histórica da problemática da Claridade. Neste

\footnotetext{
${ }^{2}$ Manuel Lopes, “Tomada de Vista”, Claridade, no 1, São Vicente, Cabo Verde, Março de 1936, p.5.

${ }^{3}$ Pedro de Sousa Lobo, “A Originalidade Humana de Cabo Verde”, Claridade, no 9, São Vicente, Cabo Verde, Dezembro de 1960, p.68.
} 
sentido, propomos fazer uma reflexão sobre a forma como a imagem e a pertença do arquipélago foi pensada, representada e veiculada discursivamente pelos ensaios de pendor etnográfico e sociológicos publicados nesta revista. Portanto, neste contexto, quando falamos de discursos de definição do lugar de Cabo Verde no quadro do mundo colonial português torna legitimo questionar se estamos perante um discurso ancorado na apropriação da ideia de "autenticidade" (entendendo aqui "autenticidade" como uma singularidade contestatária e reivindicativa da diferença)? Ou um discurso ambivalente e oscilatório, tributário de um modelo de identificação, que buscava legitimar a aproximação ou o distanciamento de determinados elementos de pertença cultural que conferiam um maior ou menor enquadramento ou aceitação nos termos da lusitanidade ou da africanidade? Ou será ainda, um discurso insuflado pelos ventos hierarquizantes do entendimento conceptual de civilização e barbárie?

\section{O Princípio Celebratório de «Fincar os Pés na Terra»}

Remonta a Março de 1936 quando um grupo de intelectuais decidiram, sob o princípio fincar os pés na terra, dar à estampa um projecto cultural e literário consubstanciado materialmente numa revista denominada Claridade revista de arte e letras. Esta teve como principais figuras fundacionais Jorge Barbosa, Manuel Lopes, Baltasar Lopes e outros colaboradores iniciais como Pedro Corsino de Azevedo e João Lopes. O centro editorial da revista era a cidade do Mindelo (Ilha de Sáo Vicente - Cabo Verde) e teve como primeiro director Manuel Lopes. No primeiro ano - 1936 - foram publicados dois números que, em termos de conteúdos, oscilavam entre poesia, ensaio, recolha etnográfica, literatura, etc. Isto é, "essencialmente literária nos seus três primeiros números, nem por isso deixam de nela aparecer notas que apontam não só para as características sociais de Cabo Verde mas também para as suas raízes humanas e telúricas, conferindo ao dialecto de Cabo Verde uma presença de honra. Com efeito, logo nos dois primeiros números se publicam, na página de rosto, poemas em crioulo..." ‘. Há que realçar que a publicitação do crioulo constituía uma forma de manifestação do regionalismo caboverdiano na sua vertente linguística, como veremos mais adiante, uma vez que a Claridade via o crioulo como uma variante dialectal do português metropolitano.

Conhecedores de outras tendências estéticas e literárias, como as que foram veiculadas pela revista coimbrã Presença, foi sobretudo ao modernismo do nordeste brasileiro que os Claridosos foram buscar precursores, influências e modelos literários que melhor encaixavam na interpretação da realidade do arquipélago. Para Manuel Lopes, "o modernismo brasileiro com Manuel Bandeira e Ribeiro Couto, que exerceram forte

\footnotetext{
${ }^{4}$ Manuel Ferreira, No Reino de Caliban I - Antologia panorâmica da poesia africana de expressão portuguesa: Cabo Verde e Guiné-Bissau, 3a edição, Lisboa, Plátano Editora, 1988, p. 87. Refere a finaçom (cantiga popular) que veio publicada na capa de rosto do primeiro número da revista; e também de uma morna - Venus - de Xavier da Cruz, no segundo número. O autor alerta para se ter em atenção algum sentido de rigorosidade, uma vez que não são os elementos culturais africanos que adquirem importância, mas sim os elementos crioulos, o produto de uma aculturação, já sem conflitos, que ganham um fundo valor nos propósitos dos claridosos.
} 
influência em Cabo Verde, com Jorge de Lima, Mário de Andrade e outros, deixaram o terreno adubado, onde a resposta do Norte, quero dizer, os romancistas do Nordeste, lançariam as raízes abundantes da prodigiosa brasilidade moderna - com os romances do povo e da terra, precisamente aquele povo e aquela região táo lembrados quando se pretende evocar certas afinidades entre cabo-verdianos e brasileiros" ${ }^{\text {. }}$. A adopção do nordeste brasileiro, como modelo de apoio e de identificação para explicar o caso caboverdiano, constitui uma forma de manifestação da ideia de irmandade elaborada com base numa cosmovisão veiculada através das personagens e do retrato narrativo de uma realidade específica nos romances dos escritores nordestinos. Esta nossa asserção da ideia de irmandade pode ainda ser sustentada por Manuel Lopes que se pronuncia nos seguintes termos: "tivemos a impressáo de que a voz que vinha do sul pertencia a um irmão, mais rico e mais corpulento, mas irmão"6. Por isso, "muitos caboverdianos se tornaram conscientes das afinidades existentes entre as suas ilhas crioulas e o Brasil chamado "clássico", isto é, a faixa litorânea do nordeste, cujos alicerces sociais foram a escravidão africana, a miscigenação, e a consequente mistura cultural. Outrossim, o sertão árido do nordeste brasileiro, flagelado com regularidade pela seca, sofria os mesmos problemas sociais que Cabo Verde, também vítima das secas. Daí a identificação que muitos caboverdianos sentiram ao tomarem conhecimento das obras de José Lins do Rego, Graciliano Ramos e Jorge amado"7.

A eclosão da Claridade foi por vezes "entendida como o arranque decisivo de uma literatura de alcance "nacional", ou "regional" - talvez eufemismo necessário, dada a

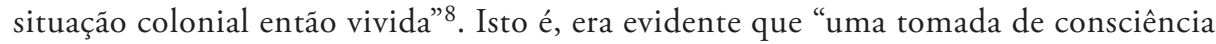
regional muito nítida se instala nos escritores de Cabo Verde, que decidem romper com os arquétipos europeus e orientar a sua actividade criadora para as motivaçóes de raiz cabo-verdiana. Não é ainda uma posição anti-colonial. Não é ainda, nem nada que

\footnotetext{
${ }^{5}$ Manuel Lopes, "Reflexões Sobre a Literatura Cabo-Verdiana ou a Literatura nos Meios Pequenos", in Colóquios Cabo-Verdianos, Lisboa, Junta de Investigação do Ultramar, 1959, p. 16.

${ }^{6}$ Ibidem, p.17. Salienta ainda Manuel Lopes que as personagens dos romances nordestinos náo eram desconhecidas em Cabo Verde. Dir-se-iam gente saída do nosso povo e vivendo problemas brasileiros. A «solução" brasileira pareceu a alguns escritores do pequeno arquipélago a "solução» cabo-verdiana. Qualquer coisa nessa literatura dava aos cabo-verdianos a ilusão do já visto. Por isso, nessa primeira hora, foi a mensagem, a resposta esperada. Evidentemente os fenómenos ecológicos eram engendrados por uma geografia física e humana, e problemas económicos e sociais completamente diversos - motivo por que alguns escritores cabo-verdianos teriam aceitado só parte da mensagem brasileira, senão, apenas, o exemplo do intelectual brasileiro que soube curvar-se sobre os problemas da terra e do homem, e trazer-nos o testemunho atento e sensível da sua viva realidade quotidiana.

${ }^{7}$ David Brookshaw, A Busca da Identidade Regional e Individual em Chiquinho e o Movimento Claridade, Paris, Fundation Calouste Gulbenkian, Centre Culturel Portugais, 1985, p. 186.

${ }^{8}$ Sérgio Neto, "Cabo-verdianidade e Luso-tropicalismo: Duas visôes de Cabo Verde em tempos de Estado Novo”, Estudos do Século XX, no 3, 2003, p.301. Acrescenta ainda o mesmo autor que o aparecimento da Claridade foi saudado pela Presença e pelo Notícias de Cabo Verde, do seguinte modo: "alta afirmação do valor intelectual de Cabo Verde, que marcará entre os melhores da actual vanguarda portuguesa”, reconhecendose, desde muito cedo, a "audácia" da página inicial, verdadeiro manifesto da cabo-verdianidade, com três poemas em crioulo”. A mesma opinião tem Luís Romano ao escrever que "em Portugal, Presença recebe carinhosamente Claridade". (Luís Romano, "O Caso Caboverdeano na Moderna Literatura”, Vértice Revista de Cultura e Arte, vol. XIV-131-132, Agosto/Setembro, 1954, p. 488).
} 
se pareça, algo que tenha a ver com a ideia de independência política ou nacional"9. Mas independentemente da orfandade política, ideológica e combativa do projecto Claridade face à realidade colonial do arquipélago, o que náo podemos negligenciar é que a Claridade, enquanto projecto literário, tornou-se no núcleo importante das actividades intelectuais e literárias da época. Do ponto de vista da literatura, a realidade arquipelágica (homem, terra, ambiente, mar, insularidade...) converte-se no objecto de descrição e de elaboração ficcionista.

Temos que saber reconhecer que, apesar do estatuto de Cabo Verde enquanto colónia, o surgimento da Claridade representava duas vertentes contraditórias de uma mesma realidade. A primeira é a afirmação de uma consciência regional e da tentativa de descodificação das raízes culturais e da estrutura social mestiça, crioula caboverdiana; a segunda é a passividade da Claridade e a sua posição não combativa da situação e da dominação colonial, assumindo o regionalismo como manifestação de pertença a um "mundo". Muito embora, temos que ter alguma reserva e náo ser táo categóricos em considerar que a afirmação de uma consciência requer necessariamente um sentido combativo, contestatário ou de luta ${ }^{10}$. Entretanto náo podemos deixar de sublinhar que este posicionamento da Claridade representava uma manifestaçáo ambivalente da produção cultural da intelectualidade caboverdiana visto que, por um lado, "o que se impunha era pensar "o nosso problema», isto é, o problema de Cabo Verde" 11 ; por outro lado, parece irónico e paradoxal a busca de justificação do regionalismo do caso caboverdiano como forma de melhor enquadrar o arquipélago no contexto do mundo lusotropical. A justificação do caso caboverdiano pelos claridosos, através do estudo, da busca e explicação das raízes sócio-culturais, parece ser uma manifestação da exaltação da missão civilizadora de Portugal; da busca de fidelidade à identificação com os códigos civilizacionais do colonizador; e da vassalagem em aceitar passivamente o regime colonial sob a retórica do progresso e da ideia de desenvolvimento civilizacional. Por isso, o paradoxo da Claridade oscilava entre a afirmação de uma consciência identitária regional, vassala dos códigos civilizacionais ocidentais, mas fiel às explicitaçóes teóricas que explicavam casos semelhantes como o Brasil e que fundamentavam a maior aproximação possível e a inclusão do arquipélago no mundo lusotropical. No intuito desse desiderato, a Claridade e os seus intelectuais estavam a tentar formatar um sentido de regionalismo que encaixava nos padróes da

\footnotetext{
${ }^{9}$ Manuel Ferreira, Literaturas africanas de expressão portuguesa I - Introdução Geral, Cabo Verde, S. Tomé e Principe, Guiné-Bissau, 1a edição, Amadora, Instituto de Cultura Portuguesa, 1977, pp. 37-38.

${ }^{10}$ Por exemplo, Anthony D. Smith, A identidade Nacional, 1.a ed., Lisboa, Gradiva, 1997, p. 96. Salienta que "é muito plausível encontrar uma população que manifeste um elevado grau de consciência nacional, sem ter nada que se assemelhe a uma ideologia ou a uma doutrina da nação, e muito menos a um movimento nacionalista”. Partindo deste pressuposto somos de opinião que devemos ter alguma reserva em exigir que a Claridade tivesse uma postura combativa e contestatária da situação colonial. Por outro lado, náo deixa de parecer ambígua a ideia de uma suposta consciencialização nacionalista, quando a Claridade é interpretada à luz das categorias matriciais do nacionalismo, na medida em que, enquanto projecto, ela náo constituía uma tomada de consciência fundamentada nem pela necessidade política de subverter as relaçóes de poder, nem pela força da razão de distanciamento cultural da comunidade das ilhas em relação à metrópole.

${ }^{11}$ Manuel Ferreira, No Reino de Caliban I Antologia panorâmica da poesia africana de expressão portuguesa Cabo Verde e Guiné-Bissau, $3^{a}$ ediçấo, Lisboa, Plátano Editora, 1988, p. 86.
} 
civilização Lusa: "na sua ânsia de aproximar Cabo Verde de Portugal, a elite letrada ergue uma inegável aporia hermenêutica na qual o regionalismo cabo-verdiano não chega a expressar a particularidade da civilização cabo-verdiana, mas sim a da portuguesa" 12 . Entendemos então que o regionalismo era uma manifestação da auto-percepção e autorepresentação discursiva da identidade caboverdiana no quadro do mundo lusotropical. Daí a afirmação e aceitação, pelos intelectuais da Claridade, do regionalismo caboverdiano como experiência bem sucedida do mundo criado pelos portugueses, entendido à luz do lusotropicalismo de Gilberto Freyre. Esta ancoragem estética (nos modelos literários) e hermenêutica (nos postulados de Gilberto Freyre) da Claridade, paradoxalmente, não constituía uma manifestação de rompimento com Portugal, mas sim uma tentativa de justificação da especificidade lusotropical do caso caboverdiano. Neste caso o regional é concebido como apêndice ou prolongamento da extensấo universalista da identidade lusa; e, parte integrante do mundo lusotropical criado por Portugal.

\section{Claridade, Caboverdianidade e Lusotropicalismo}

Se a Claridade surge como revista de arte e letras, com uma forte componente poética, literária e artística, porém ela não deixou de ser um órgão e um veículo cultural que, na sua vertente ensaística, produziu estudos de índole sociológica, etnográfica e de carácter diverso.

Uma suposta concepção da caboverdianidade era sustentada por uma certa ideia de regionalismo. Regional, como já assinalámos, enquanto identidade filiada na extensão universalista lusa da identidade lusotropical criada por Portugal; e, ainda regional, no sentido em que a caboverdianidade não constituía uma forma de reivindicação da especificidade africana. Sendo assim, o regionalismo ganha uma conotação territorializante enquanto espaço que, devido à sua natureza insular, moldou e definiu os contornos, as particularidades e as características da mundivivência e da idiossincrasia sócio-cultural e antropológica caboverdiana. Deste modo, a suposta defesa de um Cabo Verde enquanto região constituía aquilo que os intelectuais claridosos pretendiam comunicar discursivamente sobre o modo de auto-categorização e auto-identificação no contexto do mundo colonial português.

\section{Caboverdianidade: uma versão regional do lusotropicalismo?}

A convicção da singularidade social e cultural do arquipélago, como consequência da historicidade da sua formação, fez com que a noção de caboverdianidade fosse elevada à categoria de conceito caracterizador da comunidade das ilhas. Sendo assim, podemos considerar que "para os "claridosos», a caboverdianidade era o sine qua non da sua ideia de reivindicação etnocultural"13.

\footnotetext{
${ }^{12}$ Gabriel Fernandes, A Diluição da África - Uma interpretação da saga identitária cabo-verdiana no panorama político (pós)colonial, Florianópolis, Editora da Universidade Federal de Santa Catarina, 2002, p. 84.

${ }^{13}$ Russel Hamilton, Literarura Africana, Literatura Necessária II, ..., Lisboa, Edições 70, p. 124.
} 
Se desde um primeiro momento podemos referir a uma espécie de aproximação dos Claridosos em relação à literatura do nordeste brasileiro, por sua vez, no âmbito hermenêutico da dissertação sobre as raízes culturais do arquipélago, os Claridosos vão buscar o suporte teórico nas ideias de Gilberto Freyre. Manuel Lopes é peremptório em afirmar que "no ensaio de sociologia e etnografia um livro portentoso exerceu grande influência entre os caboverdianos: Casa Grande e Senzala, de Gilberto Freyre"14. Então Casa Grande e Senzala converteu-se no livro sagrado de enunciação das primeiras premissas básicas daquilo que viria a constituir o lusotropicalismo. É sobretudo no $O$ mundo que o português criou (1940), que a teoria ganha um sentido de generalização e de extrapolaçáo para interpretação e enquadramento teórico de outros espaços coloniais do mundo português a ponto de Freyre chegar a afirmar que "Portugal, o Brasil, a África e a Índia Portuguesas, a Madeira, os Açores e Cabo Verde constituem hoje uma unidade de sentimento e de cultura" ${ }^{15}$. No seio dos Claridosos Gilberto Freyre converteu-se num teórico de referência a ponto de ser um dos escritores mais discutidos e apreciados; dos que mais vincadamente impressionaram os elementos do chamado grupo da revista Claridade. Essa idolatria era também visível na fidelidade em relação à obra, na medida em que "houve quem dormisse com Casa Grande e Senzala na banquinha da cabeceira e o manuseasse com o mesmo fervor com que os crentes lêem as Sagradas Escrituras"16. A admiração pelo apóstolo do lusotropicalismo estava patente também na desejada visita que os Claridosos tanto ansiavam do profeta para a confirmação da especificidade do caso de Cabo Verde no quadro do mundo lusotropical. O desejo e a ânsia por uma possível visita de Gilberto Freyre estava na crença dos Claridosos de que os elementos da comunidade das ilhas encaixavam plenamente na interpretação lusotropicalista: "estou convencido de que todos os elementos se acham prontos a prestar informaçóes ao ilustre hóspede, aparecendo para conversar com quem é de há muito conhecido deste rincão luso, através das páginas das suas obras. Estes e outros igualmente habilitados, que os há, terão de saber reunir material digno de ser observado por quem nada mais deseja do que verificar a realidade de - o mundo que o português criou" ${ }^{17}$. Entretanto, independentemente dos objectivos políticos preconizados pelo Estado Novo com a visita de Freyre os Claridosos anteviam um único propósito: certificar o caso caboverdiano como uma tradução e parte integrante da civilização lusotropical ${ }^{18}$. Por isso, se o lusotropicalismo tentava explicitar a universalidade do mundo português, então a caboverdianidade

\footnotetext{
${ }^{14}$ Manuel Lopes, Art. cit., p. 16.

${ }^{15}$ Gilberto Freyre, O Mundo que o Português Criou, 2a edição, Lisboa, Edição "Livros do Brasil», 1940, p.39. Acrescenta Freyre que essa unidade, íntima de sentimento e externa de cultura, nas suas formas mais evidentes e concretas, é consequência dos processos e das condiçóes de colonização portuguesa que na Ásia como no Brasil, nas ilhas do Atlântico e até certo ponto na África, desenvolveram nos homens as mesmas qualidades essenciais de cordialidade e de simpatia, características do povo português.

${ }^{16}$ Teixeira de Sousa, "Uma visita desejada", Cabo Verde - Boletim de Propaganda e Informação, n. ${ }^{\circ} 27$, Praia, Dezembro, 1951, p. 31.

${ }^{17}$ Ibidem, pp. 31-32.

${ }^{18}$ Víctor Barros, "Lusotropicalismo e Caboverdianidade: o discurso de Gilberto Freyre e o contradiscurso de Baltasar Lopes”, Comunicação apresentada no II Encontro de Jovens Investigadores Caboverdianos, Praia, 22 de Dezembro, 2007 (Prelo).
} 
não podia deixar de ser uma versão regional da especificidade lusa nos trópicos. Do exposto fica claro que a adesão às ideias enunciadas por Gilberto Freyre se tornou significativa na concepção e interpretação do real arquipelágico; daí que, com base nesse modelo, a revista Claridade ficasse "possuidora de um esquema de interpretação do real em que a parte mais significativa se deve a Gilberto Freyre" ${ }^{19}$. Por exemplo, nos vários números da revista, a tendência orientadora em seguir Gilberto Freyre é clara, tanto no texto de João Lopes quando afirma que "a evolução tem de fazer-se, como diz Gilberto Freire para o Brasil, no sentido de todas as forças de cultura terem inteira oportunidade de expressão criadora"20; ou ainda em Baltasar quando escreve que "o eminente sociólogo brasileiro Gilberto Freyre, nas suas CONFERÊNCIAS NA EUROPA, reeditadas em 1940 com o título O MUNDO QUE O PORTUGUÊS CRIOU, apresenta um ponto de vista rico de sugestóes e que, quando transportado para o problema linguístico, está de acordo com o que suponho ser a tenacidade românica nos territórios ultramarinos de cunho português" ${ }^{21}$. Até do ponto de vista linguístico, Baltasar Lopes considera Cabo Verde como um caso à parte; isto é, como uma "experiência românica nos trópicos". Salienta ele que "tendo chegado as ilhas, de um modo geral, à aceitação da cultura europeia, a linguagem se aproxime cada vez mais do português da Metrópole..."22. Nesta mesma linha analítica ele considera que "não causa também estranheza, por esta razão, que as sobrevivências lexicais de origem africana sejam actualmente pouco numerosas no arquipélago, e em Barlavento quase insignificantes" 23 . Por isso Baltasar afirma, primeiro, que "o crioulo de Cabo Verde é uma linguagem nitidamente românica, portuguesa" ${ }^{44}$; segundo, que "os crioulos (linguagens negro-europeias) correspondem à miscegenação de tipos humanos" ${ }^{25}$; e por esta razão considera que "[...] o caboverdiano é um tipo linguística e culturalmente definido, irmão do brasileiro" 26 .

Feitas estas consideraçóes, somos levados a salientar que Baltasar Lopes define o homem caboverdiano como sendo falante de um dialecto resultante da experiência

${ }^{19}$ Mário António F. Oliveira, Reler África, Coimbra, Instituto de Antropologia, Universidade de Coimbra, 1990, p. 249.

${ }^{20}$ Ibidem.

${ }^{21}$ Baltasar Lopes, "Uma Experiência Românica Nos Trópicos I", Claridade, no 4, São Vicente, Cabo Verde, Janeiro, 1947, p. 15. Maiúsculas no original.

22 Ibidem, p. 19.

${ }^{23}$ Ibidem.

${ }^{24}$ Baltasar Lopes, "Notas para o estudo da linguagem das ilhas", Claridade, no 2, São Vicente, Cabo Verde, Agosto, 1936, p.5. Fundamenta que é uma linguagem nitidamente românica, portuguesa uma vez que o seu sistema morfológico resulta directamente de uma simplificação da morfologia do português. Seu léxico é quase totalmente português. O vocabulário africano deixou fraquíssimos vestígios, principalmente nas ilhas de Barlavento; em Santiago é que se encontra maior número de vocábulos africanos, topónimos e nomes comuns e mesmo assim em percentagem ínfima.

${ }^{25}$ Ibidem. Porque, escreve Baltasar, para a formação do crioulo de Cabo Verde, sabemos que o português trouxe o seu vocabulário e a sua gramática, que o afro-negro simplificou: - a este, em maior número, coube a acção patológica que modificou a linguagem, imprimindo-lhe certa feição.

${ }^{26}$ Baltasar Lopes, "Uma Experiência Românica Nos Trópicos I”, Claridade, no 4, São Vicente, Cabo Verde, Janeiro, 1947, p. 22. 
românica portuguesa nos trópicos; uma experiência humana e também cultural na qual se verifica o pouco [ou quase inexistente] predomínio do elemento não-europeu na vida e na história do dialecto, como também nas várias formas de manifestaçôes culturais, dado que as reminiscências "selvagens" da África foram liquefeitas ou diluídas num processo de adaptaçáo de motivos europeus. Deste ponto de vista podemos sustentar que Baltasar Lopes medeia o enquadramento cultural de Cabo Verde, no âmbito do então considerado mundo tropical sob a pertença de Portugal ${ }^{27}$; ao mesmo tempo, medeia culturalmente o posicionamento de Cabo Verde na intersecção entre o mundo considerado "civilizado" e o mundo considerado "selvagem".

Portanto, os intelectuais da Claridade constituíram-se no "primeiro centro, fora do Brasil, orientado para a interpretação global de uma sociedade luso-tropical" 28 . Então, não sendo verdade considerar que a caboverdianidade foi pensada como uma versão regional do lusotropicalismo, como é que explicaríamos a indignação da elite intelectual claridosa em relação à não confirmação e não corroboração de Cabo Verde, como um caso bem consumado da família lusotropical, aquando da visita de Freyre em 1951? Isto é, como justificar a reacção de Baltasar Lopes pronunciada anos depois (1956) em relação à evidente africanidade do arquipélago referida por Gilberto Freyre? $\mathrm{Ou}$, como justificar a afirmação de Baltasar pronunciada nestes termos: "O Messias desiludiu-nos"29?

\section{O discurso claridoso da intersecção civilizacional entre a Europa e África}

Como já tivemos oportunidade de explicar, a Claridade foi um centro de produção e de veiculação de uma imagem e de discursos. Se, por um lado, não podemos negligenciar o contexto do exercício da apropriação lusotropicalista, por outro lado, não podemos deixar de salientar o jogo discursivo produzido numa lógica oscilatória entre a aproximação e o afastamento em relação aos elementos culturais que estiveram na base da formação da sociedade mestiça caboverdiana. Se a preocupação fundamental estava, primeiramente, em exaltar os códigos e os elementos da comunidade cultural do arquipélago até entâo entendidos como sendo adaptaçấo de motivos europeus, seguidamente, a sua justificação teórica conferia um grau de aproximação em relação à categoria de mundo civilizado e afastamento em relação às heranças ou reminiscências consideradas "selvagens". É por esta razão que consideramos que o jogo discursivo dos intelectuais da Claridade obedecia à lógica do binarismo civilização/barbárie, alimentada pelo princípio de superioridade ou de alcance a níveis ou estágios superiores de evolução. A confirmar esta afirmação, encontramos Baltasar Lopes que considera pertinente seguir a orientaçáo analítica apresentada pelo professor Artur Ramos, segundo

\footnotetext{
${ }^{27}$ Por exemplo, Russel G. Hamilton considera que em "Uma Experiência Românica nos Trópicos”, Baltasar Lopes define o lugar distintivo de Cabo Verde na família da diversidade tropical sob o domínio de Portugal. (Cf. Russel G. Hamilton, ob. cit., p. 97).

${ }^{28}$ Cf. Mário António F. Oliveira, Reler África, Coimbra, Instituto de Antropologia, Universidade de Coimbra, 1990, p. 249.

${ }^{29}$ Baltasar Lopes, Cabo Verde Visto por Gilberto Freyre, Praia, Imprensa Nacional, 1956, p. 11.
} 
a qual são três os resultados da aculturação, quando se tem em presença duas culturas - uma mais adiantada (a europeia) e outra mais atrasada (a africana) ${ }^{30}$. Essas linhas de orientação analítica adoptadas por Baltasar estão ventiladas por noçóes etnocêntricas e eurocêntricas visíveis no modo de caracterização e de categorização de culturas com base no paradigma da superioridade (mais adiantada - a europeia) e de inferioridade (mais atrasada - a africana).

Com base na adopção deste modelo interpretativo hierarquizante das relaçôes entre culturas, Baltasar considera plausível sustentar pelo menos como "hipótese de trabalho" que, nas ilhas de Barlavento e em Sotavento, na Brava e talvez no Fogo (quer dizer: na maior parte do arquipélago) se verifica a aceitação resultante de uma fase anterior de adaptaçâo, ... 31 . Baltasar Lopes refere ainda que "uma ou outra rara sobrevivência das culturas afro-negras não pode prejudicar este resultado total" 32 . E, em jeito de tese, é categórico em afirmar que "nas zonas socialmente formadas ou dominadas pelo encontro de culturas negro-africanas e europeias, Cabo Verde talvez represente o único exemplo actual, [...], da aceitação ..."33. A partir dessas categorias de avaliação - aceitação, adaptação e reacção - seguidas por Baltasar, subentende-se uma espécie de apreciação com base na determinação dos valores da hierarquia civilizacional, ao sustentar que o arquipélago alcançou o estádio de aceitaçâo, resultante de uma anterior adaptação. Daí, que a aceitação possa ser entendida como um processo de adaptação, de assunção e de maior afirmação e predomínio do elemento cultural (europeu), presentes na comunidade cultural do arquipélago, em detrimento de um processo amnésico em relação à herança cultural mais velha.

Contudo, a fraqueza deste argumento está no facto de não ter existido no arquipélago uma herança cultural mais velha que podia ser perdida ou esquecida através do contacto com a "nova cultura", dado que as duas heranças culturais (europeia/metropolitana e africana) que estiveram na base de formação sócio-cultural de Cabo Verde são coincidentes no mesmo tempo e no mesmo espaço; daí, não beneficiam nenhuma delas de uma validade espácio-temporal ancestral, secular ou milenar no arquipélago. Assim, na esteira da análise e do pensamento acima referidos, podemos afirmar que a ideia de aceitação representava em parte um certo "branqueamento" e um posicionamento um tanto ou quanto amnésico em relaçáo à presença da herança cultural africana, também co-participante na formação e na configuração da comunidade do arquipélago.

\footnotetext{
${ }^{30}$ Cf. Baltasar Lopes, "Uma Experiência Românica Nos Trópicos I”, Claridade, no 4, São Vicente, Cabo Verde, Janeiro, 1947, p.18. Esses resultados são: aceitação, adaptação e reacção. Aceitação quando a nova cultura (europeia) é aceite, com perda ou esquecimento da herança cultural mais velha; na adaptação, "ambas as culturas, a original e a estranha, combinam-se intimamente, num mosaico cultural, num todo harmónico, com reconciliação das atitudes em conflito"; há reaç̧âo "quando surgem movimentos contra-aculturativos", conservando as culturas originárias a sua força psicológica.

${ }^{31}$ Cf. Baltasar Lopes, "Uma Experiência Românica Nos Trópicos I”, Claridade, no 4, São Vicente, Cabo Verde, Janeiro, 1947, p.18. Acrescenta ainda, no mesmo texto, que o resultado da adaptação ficou facilitado e acelerado pela própria insularidade da colónia e sua exiguidade territorial, conjugadas com maiores oportunidade supervenientes de comunicação que tornaram possível uma acção mais assídua e intensa no sentido da cultura europeia, exercida pelo elemento metropolitano, (...).

32 Ibidem, p. 19.

${ }^{33}$ Ibidem. Aceitação em itálico no original.
} 
Um outro problema fundamental estava em elevar a mestiçagem a uma espécie de essencialismo capaz de liquefazer as heranças afro-negras; a libertação e dissolução dessas heranças podiam conferir um grau de legitimidade no distanciamento do legado africano, presente durante a colonização. Esta questão está explícita no modo como João Lopes problematiza a anulação da influência afro-negra devido ao processo miscigenador: "até onde teria chegado a influência das levas afro-negras? Náo sabemos, mas é de atender a que a prolongada miscigenação de cinco séculos obliterou o vigor das camadas invertidas na colonização" 34 . Nesta lógica, a obliteração do legado africano significava: primeiro, a busca de aproximação e de enquadramento nos níveis, considerados "mais avançados", de cultura; segundo, a anulação e afastamento de níveis considerados "mais atrasados" de cultura, de que se pensava que Cabo Verde se tinha distanciado. Este tipo de categorização não deixa de ser também tributário de alguma influência sobre a concepção hierárquica dos valores civilizacionais e do binarismo civilização/barbárie.

Em relação à expressão melódica ou musical, sobretudo batuque e finaçon, (este como subgénero daquele) Baltasar acredita ser lícito atribuir-lhes um "certo carácter de romanceiro, embora sem regularidade métrica" 35 ; reconhece a origem africana do batuque e salienta que, apesar de ser na ilha de Santiago que ele é celebrado, "certas sobrevivências nas ilhas de Barlavento tendem a mostrar que antigamente o batuque era cerimónia generalizada no arquipélago" 36 . Em relação aos temas tratados no batuque, Baltasar ressalta que "é curioso verificar como aquela população de rústicos sente imperiosa necessidade de se apoderar da figura que lhe cause impressão, ou da efeméride, e sobre uma e outra exercer a sua censura em termos poéticos (líricos ou satíricos) no terreiro de batuque" 37 . É também de opinião que não "parece descabido aventar a hipótese, sujeita a verificação ulterior, da sobrevivência, no folclore poético de S. Tiago, de temas da poesia portuguesa continental, tanto nos seus aspectos líricos, como nos satíricos"38. Ao referir-se às cantigas da ilha do Fogo escreve ele que "[...]) em mais de um ponto evocam irresistivelmente as cantigas de mal-dizer, ..."39; assim como, ao citar um batuque, ele náo deixa de sublinhar que "ou por mera coincidência, ou por uma real filiação temática, o sentido deste batuque sugere a acção de certas figuras femininas das cantigas de amigo" ${ }^{40}$. Baltasar remata a sua posição com a seguinte questão: "se não se trata de simples coincidência, através de que veículos teria chegado ao batuque africano plantado nos terreiros de S. Tiago este influxo da cultura poética reinol?”41. Então, no batuque, a sobrevivência dos seus aspectos poéticos,

\footnotetext{
${ }^{34}$ João Lopes, “Apontamento”, Claridade, no 3, São Vicente, Cabo Verde, Março, 1937, p. 6.

35 Baltasar Lopes, "O Folclore Poético da Ilha de S. Tiago", Claridade, no 7, Dezembro 1949, São Vicente, Cabo Verde, p. 43.

36 Ibidem, p. 46.

37 Ibidem, p. 43.

${ }^{38}$ Ibidem, p. 49.

${ }^{39}$ Ibidem, p. 49.

${ }^{40}$ Ibidem, p. 50.

${ }^{41}$ Ibidem, p. 50.
} 
líricos e satíricos seria uma herança metropolitana das cantigas ibéricas. Segundo Russel Hamilton, "não se admira que Baltasar Lopes diminua os elementos africanos a favor da hipótese de que a maior influência vem de formas poéticas ibéricas, como as cantigas de maldizer medievais" 42 .

Uma outra questão pertinente a referir neste ponto do nosso trabalho é a forma como no discurso escrito claridoso os traços e as heranças africanas ganharam algumas denominaçôes e categorizaçôes: "reminiscência selavagem" 43 ou "sobrevivências da África negra" ou simplesmente "sobrevivências" 44 . Tudo isto porque, segundo a perspectiva claridosa, essas heranças passaram por um processo de ajustamento e de adaptação, que as converteram em meras sobrevivências ou reminiscências. É nesta lógica que Félix Monteiro, ao expor algumas conclusôes sobre a Festa da Bandeira da ilha do Fogo, escreve que alguns usos e costumes importados com escravos africanos tiveram acolhimento favorável que, juntamente com o interesse dos brancos pelas danças e pelos cânticos dos negros, estimularam a preservação desses números exóticos integrados hibridamente. Estes factores fizeram retardar a desarticulação e o esquecimento total desses elementos, à semelhança do que aconteceu com as línguas africanas ${ }^{45}$. Daí, fundamenta ele, que "não resta porém a menor dúvida de que se trata de meras sobrevivências que há muito entraram definitivamente nos domínios do folclore, não representando, por isso mesmo, mais do que a petrificação de insignificantes resíduos de culturas ultrapassadas" ${ }^{46}$. Tudo isto representava uma forma de justificação de que o folclore poético do arquipélago era marcado por influência nitidamente europeia, visto que as influências de "culturas ultrapassadas" foram decompostas em detrimento de uma adaptação europeia.

O discurso identitário apoiava também as suas bases na exaltação do modelo português de colonização como fundamento de aproximação aos códigos de civilização metropolitana, desde o exemplo do Brasil, onde os Claridosos se reviam com muito orgulho, passando pelo "do nosso Cabo Verde, que bem merece a designação, que já lhe foi dada, de "Portugal Crioulo»" 47 . Ou seja, num tom interrogativo ficou questionado sobre o que se teria passado em Cabo Verde, capaz de explicar uma evolução única nos

\footnotetext{
${ }^{42}$ Russel G. Hamilton, ob. cit., p.113. Este autor acrescenta ainda que, sem termos o benefício de pesquisas e análises comparadas, seria precipitado negar a possibilidade de tais influências. Por outro lado, é bem provável que a antiga poesia galaico-portuguesa, de tradição palaciana, não viesse na bagagem cultural daqueles europeus que mais tiveram contacto com escravos em Cabo Verde. De qualquer modo, mesmo imaginando que os escravos teriam tido contacto com formas culturais praticadas pelos inquilinos das casas grandes, temos de considerar que, até ao século XIV, bem antes do descobrimento do arquipélago, as cantigas de amigo, de amor e de maldizer, tinham deixado de ser cultivadas na Península Ibérica. (Cf. pp. 113-114).

43 Baltasar Lopes, “Uma Experiência Românica Nos Trópicos I”, Claridade, no 4, São Vicente, Cabo Verde, Janeiro, 1947, p. 19.

${ }^{44}$ Félix Monteiro, "Bandeira da Ilha do Fogo - O Senhor e o Escravo Divertem-se", Claridade, n. ${ }^{\circ} 8$, São Vicente, Cabo Verde, Maio, 1958, p. 11, e p. 21.

45 Ibidem, pp. 20-21.

46 Ibidem, p. 21.

${ }^{47}$ Pedro de Sousa Lobo, "A originalidade humana de CABO VERDE”, Claridade, nº 9, São Vicente, Cabo Verde, Dezembro, 1960, p. 64.
} 
territórios ultramarinos e "essa admirável simbiose que é a criação, em pleno Trópico, de mais uma autêntica província de Portugal (sobretudo sob o ponto de vista cultural) das províncias irmãs metropolitanas?” ${ }^{48}$. Esta espécie de exaltação do modelo português ficou ainda patenteada no discurso claridoso do seguinte modo: "com gente escura criou-se, na verdade, em pleno Trópico, mais uma província de Portugal” 49 . Portanto, sendo o arquipélago concebido como uma província de Portugal, não podemos deixa de questionar os limites da ideia de nacionalismo sobre o posicionamento dos ensaios dos claridosos e da Claridade enquanto projecto cultural.

Em suma podemos assegurar que o discurso de justificação cultural era elaborado numa lógica de aproximação e de afastamento, de (maior ou menor) negação e/ou assunçáo das heranças e dos elementos culturais que melhor poderiam corroborar a pertença do arquipélago no quadro do mundo considerado luso e tropical. Então, a assunção versus negação de determinadas heranças constituía um móbil de mediação para o enquadramento na "civilização" e de justificação dessa mesma pertença. Sendo assim, então, a escala de aproximação e de afastamento poderia determinar o enquadramento "civilizacional". Então podemos considerar que a tentativa de fundamentar a aproximação e a busca da máxima identificaçáo possível dos elementos culturais do arquipélago em relação aos códigos e às heranças culturais ocidentais/ metropolitanas, constituíam uma das preocupaçóes do discurso escrito e da imagem veiculada na Claridade.

\section{As Sombras da Claridade}

Entendemos que, em função desse jogo discursivo que interpōe e busca inserir o arquipélago entre dois mundos civilizacionais - África e Europa -, o discurso identitário elaborado e veiculado produziu aquilo que podemos designar por "sombras" da Claridade. A tradução desta imagem significa, primeiramente, que consideramos que a Claridade produziu também margens de sombras; a aparente clareza do projecto produziu um lado escuro, cujo legado ainda produz sombras subentendidas e algumas reminiscências com as quais ainda [con]vivemos no arquipélago. Referimo-nos à imagem alegórica de sombras porque a tão anunciada e cristalizada luz de afirmaçáo e de consciencialização nacionalista caboverdiana, propagada e [re]produzida no período pós-independência em relação à Claridade, afinal, nunca chegou a trespassar a condição de subalternidade colonial para raiar e fazer-se luz de luminosidade nacionalista.

\section{O paradoxo da caboverdianidade}

Historicamente se, do ponto de vista da literatura, o surgimento da Claridade é um momento de afirmação e consciencialização literária, também não deixa de ser evidente que a Claridade enquanto projecto de afirmação literário e cultural suporta algumas sombras, umas vezes paradoxais, outras vezes ambivalentes. Senáo vejamos.

\footnotetext{
${ }^{48}$ Ibidem.

49 Ibidem, p. 68.
} 
Primeiro é o que consideramos ser o paradoxo da caboverdianidade, sendo esta considerada como o entendimento conceptual, o termo-síntese da identidade do arquipélago; identidade essa que se formou com base em elementos de origem europeia e africana. Por isso defendemos que uma das sombras da ideia da caboverdianidade está na não afirmação e exaltação da sua paternidade africana e na inferiorização dos componentes afro-negros da sua formação. Isto quererá dizer que "na obra propriamente literária dos escritores claridosos não se sente a herança cultural africana como uma componente importante da cabo-verdianidade" 50 . Considera-se que "os escritores caboverdeanos, nessa altura, não reivindicavam propriamente uma especificidade africana, se bem que fosse inequívoco o seu sentido da caboverdeanidade, da literatura enquanto sistema de comunicação com poder autonómico face à situação política e jurídica do arquipélago" 51 . Entendemos que o equívoco ou a ambiguidade do sentido da caboverdianidade estava justamente na não reivindicação da sua paternidade africana; isto é, não assume um posicionamento capaz de valorizar os elementos e as heranças culturais e humanas afronegras que estivaram na base da sua formação, formatação e configuração.

A consciencializaçáo dos Claridosos estava ancorada mais no carácter da teatralização ficcional do ambiente e da realidade insular que circundava o escritor/poeta ilhéu/ Claridoso. Neste domínio eles conseguiram a correspondência entre o ambiente/realidade do arquipélago e a literatura como veículo de representação do drama existencial do homem ilhéu.

Porém, a caboverdianidade significava a mesma coisa que singularidade social e cultural do arquipélago no quadro do mundo considerado português; por outro lado náo significava e nem era uma identidade distante, contrastiva e de oposição à identidade lusa. Era um apêndice; uma manifestação regional da tendência universalista da identidade lusa e da extensão desta mesma identidade como prova da capacidade integradora dos Portugueses nos trópicos. Ou seja, "luso-tropicalismo e caboverdianidade, não sendo conceitos sinónimos, teriam no entanto, uma zona de interseç̧âo" 52 . Por isso a caboverdianidade foi pensada como uma versão identitária de pendor lusotropicalista; isto é uma identidade regional co-participante e pertencente ao todo português luso e tropical.

\section{A apropriação do lusotropicalismo}

Tanto o modelo de identidade que se pretendia elaborar, como a interpretação da realidade caboverdiana, fundou as suas bases explicativas no lusotropicalismo. O lusotropicalismo fez emergir a ideia de uma espécie de "commun dénominateur" 53

\footnotetext{
${ }^{50}$ Dulce Almada Duarte, "Literatura e Identidade: Uma abordagem Sociocultural”, CULTURA, n 2, Julho, 1998, p. 12.

${ }^{51}$ Pires Laranjeira, De Letra em Riste: Identidade, autonomia e outras questóes nas literaturas de Angola, Cabo Verde, Moçambique e S. Tomé e Príncipe, Porto, Ediçóes Afrontamento, 1992, p. 12.

52 David Hopffer Almada, Caboverdianidade \& Tropicalismo, 2a sornadas de Tropicologia 1989, Recife, Fundação Joaquim Nabuco, Editora Massanga, 1992, p. 83. Itálico no original.

53 Cf. Déjanirah Couto, Armelle Enders et Yves Léonard, "Lusotropicalisme: Du Mythe à L'Objet de Recherche”, Lusotopie 1997, p. 195.
} 
partilhado pelos espaços submetidos ao modelo de colonização portuguesa. No entanto "essa fidelidade ao pensamento brasileiro não deixa de ter um aspecto irónico, já que Freyre exaltava a capacidade dos portugueses de se integrarem nos trópicos. Aceitando estas teorias, parecia que os caboverdianos também aceitavam o regime colonial" 54 . Por outras palavras, subentende-se que compactuavam com o modelo de colonização portuguesa subjacente, na sua vertente messiânica e civilizadora. Noutros termos seria dizer que a justificação da pertença e uma suposta aproximação com o modelo colonial tratar-se-ia de uma modalidade irónica do identificar-se $\mathrm{e}^{55}$. Neste caso a apropriação do lusotropicalismo deve ser problematizada nos seguintes termos: "de que modo, e por via de que modalidades de tradução, pôde a teoria freyriana da mescigenação funcionar como uma teoria emancipatória para os homens da Claridade?"56; ou seja, "como pode uma teoria de emancipaçáo, ou assim recebida, funcionar ao mesmo tempo como teoria da colonização?" 57 . Embora tenhamos também que saber contextualizar e reconhecer que a maturação da consciência combativa não se tinha ancorado e radicalizado a ponto de levantar a questão da reivindicação contestatária e da necessidade de emancipação e de ruptura com o estado colonial. Tudo isto porque a identidade não tinha sido pensada na lógica da oposição, da confrontação e do antagonismo da disputa das relaçóes de poder.

\section{Algum nacionalismo...? Que nacionalismo?}

Parece-nos insustentável e descabida qualquer hipótese sobre a possibilidade da Claridade constituir uma forma de manifestação de algum nacionalismo. Cabo Verde náo foi pensado como comunidade distanciada e diferente cuja condição de subalternidade colonial requeria a necessidade de uma ruptura política com a metrópole e a pretensão de uma autonomia própria. Cabo Verde não foi imaginado como nação política e cultural, de modo que a ideia subjacente servisse de móbil que reivindicava um posicionamento jurídico próprio, mesmo que subtilmente, nas margens da violência política e da censura vigilante do Estado Novo. Por outro lado, o que se reivindicava era uma versão de regionalismo português nos trópicos; um apêndice, um prolongamento luso no mundo dos trópicos. Daí que a Claridade estava longe de ser um meio a partir do qual os membros da comunidade cultural do arquipélago pensaram em atingir e conservar a autonomia, a unidade e a identidade em nome de uma população que alguns dos seus membros consideravam constituir uma "nação» real ou potencial ${ }^{58}$.

\footnotetext{
${ }^{54}$ David Brookshaw, A Busca da Identidade Regional e Individual em Chiquinho e o Movimento Claridade, Paris, Fundation Calouste Gulbenkian, Centre Culturel Portugais, 1985, p. 187.

55 Cf. Gabriel Fernandes, ob. cit., p. 98.

${ }^{56}$ Osvaldo Silvestre, "A Aventura Crioula Revisitada: Versōes do Atlântico Negro em Gilberto Freyre, Baltasar Lopes e Manuel Ferreira”, in ACT 6 - Literatura e Viagens Pós-coloniais, org. Helena Carvalhão Buescu e Manuela Ribeiro Sanches, Lisboa, Ediçóes Colibri, p. 65.

${ }^{57}$ Ibidem, pp. 65-66.

${ }^{58}$ Anthony D. Smith, A Identidade Nacional, 1a edição, Lisboa, Gradiva, 1997, p. 97.
} 
É de realçar ainda que, com base nas mitologias regionais com potencialidades nacionais elaboradas pela literatura brasileira, algumas posiçôes são fundamentadas no sentido de que a literatura caboverdiana "buscava simplesmente inventar essas mitologias para poder afirmar-se, de modo subreptício, como projecto cultural nacionalista, isto é, anti-colonial" 59 . Há ainda, acerca dos claridosos, outra posição aventada segundo a qual "o grupo é nacionalista camuflado" 60 . Não corroboramos estas hipóteses porque a literatura caboverdiana claridosa náo se organizou como um projecto nacionalista e anti-colonial; porque em nenhum momento foi questionada a situação colonial do arquipélago numa perspectiva de afirmação emancipatória; também porque não foi contestada a necessidade de correspondência entre a possível unidade cultural da comunidade arquipelágica e uma potencial unidade política. E muito menos esta literatura se assemelhava a um movimento ideológico ou doutrina para exaltação e constituiçáa de uma naçáo, visto que Cabo Verde era simplesmente pensado como sendo uma província metropolitana dos trópicos.

Pensamos que uma literatura, enquanto projecto cultural nacionalista ou anti-colonial deveria obedecer à lógica doutrinária de formação das consciências e de exortação dos propósitos combativos, ou também estar ancorada numa consciência que busca traduzir o propósito de luta que passa, por conseguinte, por um processo de denúncia da situação através dos seus textos literários; mobilização e apelo à lealdade dos membros da comunidade quanto à necessidade de luta. Mas foi sobretudo na geração literária póstuma à dos Claridosos que a Claridade conheceu maiores críticas por parte de uma geração filiada e engajada noutros propósitos: a luta anti-colonial. A radicalização do discurso fez com que a Claridade fosse conotada como sendo uma literatura "ferida de autenticidade" ${ }^{61}$, que "não traduz nem produziu uma mentalidade consciencializada" 62 e que por conseguinte era uma literatura imbuída "duma erudição que não tinha em conta as realidades sócio-culturais do arquipélago, foram-se distanciando das massas de que inicialmente faziam parte ..." 63 ; concluindo então que "o enraizamento tentado pelos componentes do grupo resultou numa atitude literária inoperante" 64 .

Mesmo reconhecendo, parcialmente, a pertinência destas críticas, porém não podemos pensar e exigir uma relação directa entre a condição colonial e a emergência automática de uma literatura de combate. Se à história cabe o processo de julgamentos sucessivos das geraçôes, entáo temos que saber reconhecer que cada geração assume um compromisso histórico próprio em função dos desafios e das respostas que buscam para responder aos intentos e anseios dessa mesma geração. Cada geração é fruto de uma época, e cada época, marca a necessidade de um tipo de luta e de mediação específica, de forma a responder às ambiçôes da geração actuante. Daí que, mesmo

\footnotetext{
${ }^{59}$ Pires Laranjeira, De Letra em Riste: Identidade, autonomia e outras questóes nas literaturas de Angola, Cabo Verde, Moçambique e S. Tomé e Príncipe, Porto, Ediçôes Afrontamento, 1992, p. 43.

${ }^{60}$ Pires Laranjeira, Literatura Calibanesca, Porto, Ediçōes Afrontamento, 1985, p. 112.

${ }^{61}$ Onésimo Silveira, Consciencializaçāo na Literatura Caboverdiana, Lisboa, Edição da Casa dos Estudantes do Império, 1963, p. 8.

62 Ibidem.

${ }^{63}$ Ibidem, p. 9.

${ }^{64}$ Ibidem.
} 
não sendo politicamente combativa na denúncia da condição colonial, não podemos deixar de sublinhar que os intelectuais do grupo Claridade "empreenderam a tarefa colectiva e histórica de enraizar as letras caboverdianas"65. Por sua vez, a existência de uma consciência nacional não implica necessariamente uma postura contestatária dado que "é muito plausível encontrar uma população que manifeste um elevado grau de consciência nacional, sem ter nada que se assemelhe a uma ideologia ou a uma doutrina da nação, e muito menos a um movimento nacionalista" ${ }^{36}$. Consideramos que a questão fundamental está na forma como a consciência nacional é [re]vestida de conteúdos pelos intelectuais que, por seu turno, produzem discursos identitários capazes de corresponder à ideia e à imagem da comunidade cultural imaginada.

Feitas estas consideraçôes, quais sâo os limites para considerarmos que estamos perante um projecto cultural literário nacionalista e anti-colonial? Ou, até que ponto se torna legítimo uma geração exigir à geração anterior posturas e respostas combativas de desafios que ganham maior acuidade num momento histórico específico? Com isto queremos dizer que a postura passiva da Claridade, em relação ao domínio colonial, não descarta a possibilidade da existência de uma "consciência"; mas, perguntamos, que consciência? Que pertença? Que limites e que Nação?.

Com base numa análise comparativa entre os Claridosos e os seus precursores brasileiros, Pires Laranjeira considera que "os escritores brasileiros empenham-se em confirmar um país, uma nação; os caboverdeanos, em fundamentá-los culturalmente" 67 . Nesta mesma linha está uma outra posição segundo a qual "na apropriação desse espaço cultural que emergiu da mestiçagem que deu nascimento à nossa cultura crioula, os claridosos, sentiram-no como uma nação cabo-verdiana, não como colónia portuguesa de Cabo Verde" 68 . Não subscrevemos estas posiçôes por várias razóes. Senão vejamos. Partindo do princípio que a Claridade não revelou uma consciência de pertença e uma identidade distinta e de oposição ao colonizador, então de que modo torna pertinente considerar que os claridosos tentavam fundamentar culturalmente um país, uma nação? Que Nação...? Ou melhor, como é que, através dos seus textos veiculavam a representação imaginária da Nação? Uma região [nação] dentro de uma [outra] Nação?

Fundamentar culturalmente uma nação passa pela definição da identidade dessa nação enquanto comunidade cultural caracterizada por uma identidade singular, "autêntica" e distinta. A Claridade buscava fundamentar culturalmente o arquipélago não como nação (com uma consciência de pertença e uma identidade distinta da metrópole ou distinta da África), mas sim como uma região ou província tropical de

${ }^{65}$ Manuel Duarte, "Caboverdianidade e Africanidade", Vértice Revista de Cultura e Arte, vol. XIV-134, Novembro, 1954, p.643. Porém, outras posições discutíveis são aventadas como a que considera que a "Claridade não é uma afirmação de independência literária, cultural e, menos ainda, nacional”, Cf. Osvaldo Silvestre, "A Aventura Crioula Revisitada: Versôes do Atlântico Negro em Gilberto Freyre, Baltasar Lopes e Manuel Ferreira", in ACT 6 - Literatura e Viagens Pós-coloniais, Organização: Helena Carvalhão Buescu e Manuela Ribeiro Sanches, Lisboa, Ediçôes Colibri, p. 75.

${ }^{66}$ Anthony D. Smith, ob. cit., p. 96.

${ }^{67}$ Pires Laranjeira, De Letra em Riste: Identidade, autonomia e outras questóes nas literaturas de Angola, Cabo Verde, Moçambique e S. Tomé e Príncipe, Porto, Ediçóes Afrontamento, 1992, p. 43.

${ }^{68}$ Dulce Almada Duarte, Art. cit., CULTURA, n. ${ }^{\circ}$ 2, Julho, 1998, p. 13. 
Portugal; ao mesmo tempo que a África era vista como um espaço cujo legado tinha sido culturalmente decomposto no arquipélago pela consubstanciação da mestiçagem. Por isso, "o princípio de oposição dessa formulação de identidade regional proposta pela Claridade ao contrastar Cabo Verde à África, consolidara o projecto colonial de integração da província num todo mais amplo, que é o mundo português..." ${ }^{69}$. Sendo assim, a ideia de "nação" deslocava-se do espaço insular caboverdiano em benefício da imaginaçáo de uma pertença ao mundo considerado português; isto é, a ideia de nação descentrava-se do Cabo Verde insular e estendia-se à pertença ao universo luso e tropical do mundo Português. Por isso o homem claridoso não via o português metropolitano como um "outro" segundo o qual ele se "alterava" na diferença e na oposição, sustentada pela consciência da alteridade de um "nós” versus "eles". O "nós" aqui ganha uma conotaçáo de "nós" da regiáo tropical que, por conseguinte, encontrava-se filiado, por vários laços de aproximação cultural e identificação histórica, a "eles" da metrópole.

A perspectiva quanto à possibilidade de a Claridade representar uma forma de manifestação da existência de uma nação está também presente na enunciação feita de que "tudo leva a crer, com efeito, que a ideia de nação tenha estado subjacente a toda a reflexão dos escritores da década de 30 sobre a realidade cabo-verdiana ..."70. Do exposto perece-nos que em nenhum momento os Claridosos se referem a Cabo Verde como nação; nação, enquanto entidade com uma singularidade cultural e uma identidade que se afirma como "autêntica", idêntica a si mesma e diferente das outras naçôes. Voltaremos a salientar novamente que a ideia subjacente ao modelo identitário elaborado pelos Claridosos era concebido como regional. O que é regional é pertença ou parte de um universo maior. Neste caso a ideia de nação não é compatível com a ideia daquilo que é concebido como regional ou regiáo de pertença a um todo, porque a ideia de uma nação é alimentada pelo princípio de que uma nação é sempre (ou deve ser) pertença de si mesma.

A proposição segundo a qual "face à opressão cultural pela qual passa obrigatoriamente a dominação colonial, o colonizado, para se libertar, terá de reivindicar uma cultura específica, colocando-se numa perspectiva nacional de valorização da história e das tradiçôes do seu povo" 71 náo se aplica com rigor aos Claridosos, porque a reivindicação da especificidade cultural de Cabo Verde não constituía uma manifestação de reivindicação de uma identidade que se pensava ser autonomista, emancipatória. Dito de outro modo, se a caboverdianidade é a expressão máxima da singularidade étnica e cultural, "esta especificidade não colidia com o magistério oficial da cultura portuguesa defendido pelo regime político de Lisboa"72.

Portanto, de acordo com a ideia de pertença regional, pensavam os Claridosos que "nos dias de hoje, sociológica e culturalmente falando, Cabo Verde não é[era]

\footnotetext{
${ }^{69}$ José Carlos dos Anjos, Intelectuais, Literatura e Poder em Cabo Verde: Lutas para a definição da Identidade Nacional, Porto Alegre (Brasil) UFRGS, Praia (Cabo Verde) INIPC, 2002, p. 176.

${ }^{70}$ Dulce Almada Duarte, Art. cit., p. 13.

${ }^{71}$ Ibidem., p. 14.

72 “Claridade”, Biblos Enciclopédia Verbo das Literaturas de Língua Portuguesa, Lisboa/São Paulo, Editorial Verbo, 1995, p. 1160. O itálico não é nosso.
} 
uma entidade social em conflito condutista com o mundo lusíada em que estamos politicamente integrados" 73 , fundamentando a asserção de que "com gente escura criou-se, na verdade, em pleno Trópico, mais uma província de Portugal”74.

\section{A hierarquia dos níveis de civilização}

Não podemos esquecer que mais uma das sombras da Claridade se situava principalmente na sua ambivalência de pendor oscilatório entre a África e a Europa. Ou seja "a intersecção entre a África e Europa e entre nacionalidade e supranacionalismo português era o ponto crucial da ambivalência e do dilema dos intelectuais" ${ }^{75}$. Ventilados por paradigmas de carácter hierarquizante dos níveis civilizacionais, os intelectuais claridosos não deixaram de conceber um discurso identitário ancorado nos pressupostos do binarismo inferior/superior para justificar os níveis de "adaptação" e "aceitação" resultante da aculturação. O que parece irónico é o facto de esse binarismo estabelecer distinçôes entre as ilhas do arquipélago, quando todo o fundamento da singularidade cultural e da reivindicação de um enquadramento lusotropical passou pela defesa da caboverdianidade como uma síntese étnica e cultural bem sucedida. Esta asserção pode ser confirmada através da caracterização de níveis de inferiorização entre as ilhas. Nesta categorização de inferioridade, a ilha de Santiago era considerada como compartimento estanque devido à sobrevivência de formas de manifestaçóes culturais que revelavam ainda alguma ligação e aproximação somática à África negra. Neste caso o habitante de Santiago não beneficiou tanto das benesses da miscigenação, o que o converteu num ser de capacidade inferior, que não evoluiu. Prova bem evidente da forma como o modelo de colonização português, com base num sistema de hierarquização, elaborou categorias de diferenciação no próprio seio dos colonizados. Um exemplo bem reflectido sobretudo na "focalisation sur la promotion des mulâtres ou des Noir civilisés dans le système hiérarchique portugais, que a peut-être fonctionné au début de la colonisation" 76 .

O primeiro número da revista é elucidativo da representação desta imagem veiculada pela Claridade, quando João Lopes escreve num ensaio que "S. Tiago é em parte um compartimento estanque em Cabo Verde"77. Isto justificava-se pela maior permanência das práticas afro-negras no folclore da ilha. Sendo assim, torna-se assim evidente a manifestação das influências de paradigmas de caracterização cultural. A permanência da "África” era sinónimo de inferioridade cultural e civilizacional. Esta

\footnotetext{
73 Pedro de Sousa Lobo, "A originalidade humana de CABO VERDE”, Claridade, nº 9, São Vicente, Cabo Verde, Dezembro, 1960, p. 67.

${ }^{74}$ Ibidem, p. 68.

75 Russel G. Hamilton, ob. cit., p. 98.

${ }^{76}$ Rémy Lucas, “Aventura e Rotina: Gilberto Freyre et L'Afrique”, Lusotopie 1997, p. 239.

77 João Lopes, “Apontamento", Claridade, no 1, São Vicente, Cabo Verde, Março, 1936, p. 9. Neste mesmo ensaio João Lopes refere que "o badio, isolado, não beneficiou na mesma medida dos seus irmãos das outras ilhas das consequências da miscigenação e da interpenetração de culturas que marcaram a acção do colonizador português”.
} 
tese pode ser corroborada pela enunciação feita de que “o habitante de Sant'Iago é o de menor desenvolvimento intelectual, por ser mais puramente africano, por ser menor nessa ilha a obra de miscigenação, por aí ainda influir o "éthos" da África negra"78. Os Claridosos consideravam que, em contraposição com a ilha de Santiago, onde predominava o pitoresco e o exótico resultante da não decomposição do "ethos" da África negra, estavam as ilhas do grupo de Barlavento. Baltasar Lopes foi peremptório em afirmar que "quase não temos pitoresco em Barlavento. As próprias festas e danças de S. João, que alguns "senhores sérios" catedraticamente taxam de reminiscência "selvagem", não passam possivelmente de adaptação de motivos europeus"79. Esta mesma orientação analítica está também patente no texto de Manuel Lopes, quando escreve que "é vulgar verem-se desembarcar nestas ilhas africanas, principalmente em S. Vicente, estrangeiros sedentos de exotismos, com aquela doentia curiosidade de quem pisa terras de África e, por conseguinte, terras de mistério, e que ao cabo de meia hora de cirandagem, tornam a embarcar desiludidos e azedos, porque nada de novo colheram, nenhum mistério desvendaram: não viram manipansos, não assistiram sequer a uma sessão de magia negra" ${ }^{80}$. A existência do pitoresco e do exótico, segundo a perspectiva claridosa, é resultado do lento processo de adaptaçâo, pelo qual passava ainda a ilha de Santiago, o que se repercutirá, por sua vez, no atraso do alcance de estádios ou níveis de aceitação.

Não admira que qualquer estádio ou nível de aculturação fosse visto como um benefício resultante da colonização portuguesa. Félix Monteiro, ao referir-se às festas de bandeira da ilha do Fogo, não deixa de sublinhar que "as Bandeiras, com todas as alteraçóes sofridas através dos tempos, constituem um documento valioso a testar a vitalidade e a persistência das tradiçôes introduzidas em Cabo Verde pelos colonizadores portugueses, ao mesmo tempo que evidenciam a capacidade de tolerância e humana compreensão da grei lusitana para com os povos atrasados com os quais contactou desde os mais recuados tempos das descobertas e conquistas" 81 .

Portanto, do exposto fica a ideia fundamental de que o discurso identitário elaborado através da Claridade pretendia, entre várias outras missóes, exorcizar as heranças afronegras da caboverdianidade. Por isso entendemos que o discurso dos Claridosos punha em destaque duas questôes fundamentais: a primeira era a inferiorização dos elementos afro-negros da caboverdianidade, insuflada por algum etnocentrismo, característico de uma época de discursos racialistas e racializados; a segunda, estava em estabelecer níveis de hierarquia civilizacional entre a ilha de Santiago e as ilhas do Barlavento o

\footnotetext{
${ }^{78}$ Osório de Oliveira, "Palavras sôbre Cabo Verde para serem lidas no Brasil”, Claridade, no 2, São Vicente, Agosto, 1936, p.4. Ele exalta ainda o modelo de colonização portuguesa e faz a seguinte recomendação: "e que nós, portugueses do Continente, saibamos ver nesse entendimento de brasileiros e de caboverdeanos a melhor prova da universalidade da nossa acção espiritual, nossa glória eterna".

${ }^{79}$ Baltasar Lopes, "Uma Experiência Românica nos Trópicos I”, Claridade, no 4, São Vicente, Cabo Verde, Janeiro, 1947, p.19. Em contraposição, Baltasar reforça que, "já na ilha de S. Tiago, com as suas manifestaçôes culturais típicas (...) ainda se encontra na fase da adaptação, de que, aliás, pelas informações que tenho, certas zonas da ilha se vão afastando, em direcção à aceitação".

${ }^{80}$ Manuel Lopes, “Tomada de Vista”, Claridade, no 1, São Vicente, Cabo Verde, Março, 1936, p. 5.

${ }^{81}$ Félix Monteiro, "Bandeira da Ilha do Fogo - O Senhor e o Escravo Divertem-se", Claridade, n. ${ }^{\circ} 8$, São Vicente, Cabo Verde, Maio, 1958, p. 20.
} 
que, ironicamente, poderia pôr em causa a possível ideia de coesão da caboverdianidade enquanto termo-síntese de caracterização étnico-cultural da comunidade das ilhas. Assim, devemos ter em atenção que estamos perante uma ambivalência discursiva que oscilava entre a impossibilidade de negar por completo os elementos oriundos da África e, ao mesmo tempo, exaltar a especificidade caboverdiana em parte baseada nessa própria presença africana ${ }^{82}$. Sendo assim somos levados a concluir que a Claridade pretendia distanciar-se da África em detrimento de uma busca de aproximação e inserção no mundo considerado luso. Este afastamento era sintomático das caracterizaçóes dos valores preconceituosos e das ideologias da hierarquia civilizacional. Entende-se assim que, sob este ponto de vista, "a identidade cabo-verdiana é contrastiva em relação à África e incorporadora em relação ao olhar europeu" ${ }^{83}$, rebatendo assim a perspectiva segundo a qual "o caboverdiano, ao mergulhar nas suas raízes, voltando as costas às fontes europeias, protagoniza uma inovação que se traduz numa mudança estética do Europa-centrismo para um cosmo-centrismo - em que o homem crioulo ocupa o seu devido lugar" ${ }^{4}$. Do ponto de vista literário, esta posição é válida no sentido em que o paradigma de orientação estética ventilava e respirava a insularidade. Mas, do ponto de vista das fontes culturais, entendemos que a Claridade procurava justificar aquilo que eles denominavam por adaptação de motivos europeus; apropriação bem sucedida das heranças culturais europeias; a proximidade cultural e civilizacional de Cabo Verde em relação às fontes europeias que estiveram na génese da sua formatação.

Segundo Luís Peixeira, “a ideologia colonial encontraria resistência numa intelectualidade instruída no Seminário-Liceu, intelectualidade liberal e humanista e que identificava o conceito de cultura étnica com o conceito de nação caboverdiana" 85 . Contudo, temos que ter alguma reserva em considerar esta enunciação. Em primeiro lugar, porque os Claridosos não representavam uma intelectualidade de resistência, na medida em que saudavam o modelo de colonização portuguesa ${ }^{86}$; e, nos seus ensaios de fundamentação cultural não questionaram nem contestaram a colonização como ideologia de dominação: o programa cultural dos Claridosos não punha em causa o projecto colonial da metrópole. Portanto, estamos perante uma espécie de aclamação do

${ }^{82}$ Cf. Russel G. Hamilton, ob. cit., p. 100.

83 José Carlos Gomes dos Anjos, ob. cit., p. 85.

${ }^{84}$ Luís Manuel de Sousa Peixeira, Da Mestiçagem à Caboverdianidade: Registo de uma Sociocultura, Lisboa, Ediçōes Colibri, 2003, p. 155.

85 Ibidem, p. 156.

${ }^{86}$ Esta asserção está bem evidente na tese de Joẫo Lopes: “o facto positivo é a criação em Cabo Verde de um ambiente de grande liberdade humana, nascida desse processus sui generis absolutamente portuguez, ao invés dos colonizadores anglo-saxónicos...". ("Apontamento", Claridade, no 1, São Vicente, Cabo Verde, Março, 1936, p.9); e ainda nas enunciaçôes de Osório de Oliveira: "o alto nível mental dos caboverdeanos é, ha muito, uma das maiores provas da excelência da colonização portuguesa e da nossa capacidade civilizadora”. ("Palavras sôbre Cabo Verde para serem lidas no Brasil”, Claridade, no 2, São Vicente, Cabo Verde, Agosto, 1936, p.4); também as de Félix Monteiro sobre a: “[...] capacidade de tolerância e humana compreensão da grei lusitana para com os povos atrasados ...”. (“Bandeira da Ilha do Fogo - O Senhor e o Escravo Divertem-se”, Claridade, no 8, São Vicente, Cabo Verde, Maio, 1958, p.20); e ainda de Pedro de Sousa Lobo: "[...] essa admirável simbiose que é a criação, em pleno Trópico, de mais uma província de Portugal, ...”. (“A originalidade humana de CABO VERDE”, Claridade, no 9, São Vicente, Cabo Verde, Dezembro, 1960, p. 64). 
modelo colonial pelos próprios colonizados. Em segundo lugar, porque o entendimento do regionalismo cultural não foi sustentado pela ideia de uma nação mas sim pelo fundamento de pertença à extensão do mundo considerado português. Não se pensou numa "nação caboverdiana" fora do mundo geográfico/tropical e cultural português. E não podemos esquecer que não foram os Claridosos que pensaram que estavam a criar culturalmente uma nação. Foi sobretudo no período pós-independência, que a Claridade foi elevada à categoria de manifestação de independência literária e cultural, sob o discurso nacionalista de que a contestação literária precedeu a luta de libertação nacional.

\section{Considerações finais}

Claridade: regionalista e lusotropicalista; não anti-colonial e não nacionalista.

O aparecimento da Claridade em 1936 foi um marco importante no contexto da produção intelectual do século XX em Cabo Verde. A revista Claridade é portadora de uma carga simbólica no contexto da história da literatura de Cabo Verde. Mas, importante também foi o papel desempenhado enquanto veículo de elaboração de um discurso cultural, político e identitário na definição do lugar de Cabo Verde enquanto parte integrante mundo então considerado português. Para os Claridosos Cabo Verde representava, geográfica e culturalmente, mais uma província do então Portugal metropolitano; porém, o posicionamento cultural e político do arquipélago foi algo mediado pelo discurso de aproximação e de identificação com a metrópole, através da busca de exorcização das heranças afro-negras e da sobrevalorização da denominada "adaptação de motivos europeus". Se paradoxal parece ser a tentativa de exorcizar as heranças africanas da caboverdianidade, então a grande sombra residia não na forte insistência da africanidade da ilha de Santiago, em relação às ilhas do grupo Barlavento, mas na associação desta africanidade à inferioridade intelectual e cultural do habitante de Santiago. Neste sentido, o maior ou menor predomínio da africanidade determinava o grau de aproximação ou de afastamento em relação a África ou à metrópole (Portugal) e, por conseguinte, legitimava o discurso de defesa cultural da pertença do arquipélago a um dos dois mundos continentais.

A situaçáo de Cabo Verde no quadro da colonização portuguesa não foi questionada. Aos olhos dos Claridosos, o arquipélago não era visto como espaço de relaçóes de dominação, de distinção e de disputa de relaçôes de força no contexto do binarismo colonizador/colonizado. Daí, entendemos que não estamos perante um movimento nacionalista e muito menos anti-colonial. Quando entendemos o colonialismo como sistema de dominação, de exploração de relação de poder, de [re]produção diferenciada de identidades e de [re]produção de identidades diferenciadas, depreendemos que, com a Claridade, a questão da subalternidade colonial não foi colocada em e nos termos de diferenciação e de auto-percepção no contexto da diferença. Ou seja, o colonialismo não foi questionado como sistema binário de apropriaçáo do poder para a reprodução da condição subalterna do colonizado. Portanto, temos que ponderar e situar os limites das posiçôes que consideram a Claridade como sendo nacionalista. Ela ganhou este epíteto devido à ventilação da retórica nacionalista pós-independência que a elegeu como uma espécie de mito de fundaçáo da literatura nacional e marco 
fundacional da consciencialização cultural (nacionalista) que antecedeu à tomada de consciência política anti-colonial manifestada pela geração político-cultural das décadas subsequentes. Sendo assim, tanto a apropriação como também a exportação do lusotropicalismo, parecem ser uma postura ironicamente emancipatória de produção do discurso de amor na condição de subalternidade colonial. Assim, (usando de empréstimo o título de Christian Geffray) consideramos que as "sombras" da Claridade estão eclipsadas entre as zonas da produção do discurso de amor [luso e tropical] em tempo de servidão colonial.

\section{Bibliografia}

ALMADA, David Hopffer, Caboverdianidade \& Tropicalismo, 2as Jornadas de Tropicologia 1989, Recife, Fundação Joaquim Nabuco, Editora Massanga, 1992.

ALMEIDA, Miguel Vale de, Um Mar da Cor da Terra: Raça, Cultura e Politica da Identidade, Oeiras, Celta Editora, 2000.

ANJOS, José Carlos Gomes dos, Intelectuais, Literatura e Poder em Cabo Verde: Lutas de Definição da Identidade Nacional, Porto Alegre (Brasil) UFRGS, Praia (Cabo Verde) INIPC, 2002.

ANJOS, José Carlos Gomes dos, "A Condição de Mediador Político-Cultural em Cabo Verde: Intelectuais e Diferentes Versôes da Identidade Nacional", ETNOGRÁFICA, vol.VIII, Número 2, Lisboa, Celta Editora, 2004, pp. 273-295.

BARROS, Víctor, "Lusotropicalismo e Caboverdianidade: o discurso de Gilberto Freyre e o contradiscurso de Baltasar Lopes", Comunicação apresentada no II Encontro de Jovens Investigadores Caboverdianos, Praia, 21 de Dezembro, 2007 (Prelo).

BROOKSHAW, David, A Busca da Identidade Regional e Individual em Chiquinho e o Movimento Claridade, Paris, Fundation Calouste Gulbenkian, Centre Culturel Portugais, 1985.

CASTELO, Cláudia, "O Modo Português de Estar no Mundo»: O luso-tropicalismo e a ideologia colonial portuguesa (1933-1961), Porto, Edições Afrontamento, 1998.

“CLARIDADE”, Biblos - Enciclopédia Verbo das Literaturas de Lingua Portuguesa, Lisboa/São Paulo, Editorial Verbo, 1995.

COUTO, Déjanirah, Armelle Enders et Yves Léonard, "Lusotropicalisme: Du Mythe à L'Objet de Recherche”, Lusotopie, 1997, pp. 195-197.

DUARTE, Manuel, "Caboverdianidade e Africanidade", Vértice, vol.XIV-134, Novembro, 1954, pp. 639-644.

DUARTE, Dulce Almada, "Literatura e Identidade: Uma abordagem Sociocultural", CULTURA, no 2, Julho, 1998, pp. 7-15.

FERNANDES, Gabriel, A Diluição da África - Uma interpretação da saga identitária caboverdiana no panorama político (pós)colonial, Florianópolis, Editora da Universidade Federal de Santa Catarina, 2002.

FERNANDES, Gabriel, Em busca da Nação: notas para uma reinterpretação do Cabo Verde crioulo, Florianópolis - Brasil, Editora da UFSC (Universidade Federal de Santa Catrina), Praia - Cabo Verde, Instituto da Biblioteca Nacional e do Livro, 2006.

FERREIRA, Manuel, A Aventura Crioula: uma sintese cultural e étnica, 2a edição, Lisboa, Plátano Editora, 1973. 
FERREIRA, Manuel, Literaturas africanas de expressão portuguesa I - Introdução Geral, Cabo Verde, S. Tomé e Principe, Guiné-Bissau, $1^{\text {a }}$ edição, Amadora, Instituto de Cultura Portuguesa, 1977.

FERREIRA, Manuel, A Aventura Crioula, 3a edição revista, Lisboa, Plátano Editora, 1985.

FERREIRA, Manuel, "O Fulgor e a Esperança de uma Nova Idade", Prefácio da edição facsimilada da revista Claridade, Direcção, Organização e Orientação de Manuel Ferreira, Linda-a-velha, 1986.

FERREIRA, Manuel, No Reino de Caliban I-Antologia panorâmica da poesia africana de expressão portuguesa: Cabo Verde e Guiné-Bissau, $3^{a}$ edição, Lisboa, Plátano Editora, 1988.

FREYRE, Gilberto, O Mundo que o Português Criou, 2a edição, Lisboa, Edição «Livros do Brasil», 1940.

FREYRE, Gilberto, Novo Mundo nos Trópicos, Lisboa, Edição «Livros do Brasil», 1972.

FREYRE, Gilberto, Casa Grande e Senzala, Lisboa, Edição "Livros do Brasil», Junho 2003.

GEFFRAY, Christian, "Le Lusotropicalisme Comme Discours de L'Amour dans la Servitude", Lusotopie 1997, pp. 361-372.

GELLNER, Ernest, Naçōes e Nacionalismo, 1a edição, Lisboa, Gradiva, 1993.

HAMILTON, Russel G., Literatura Africana Literatura Necessária II - Moçambique, Cabo Verde, Guiné-Bissau, São Tomé e Príncipe, Lisboa, Ediçōes 70, 1984.

LARANJEIRA, Pires, Literatura Calibanesca, Porto, Edições Afrontamento, 1985.

LARANJEIRA, Pires, De Letra em Riste: Identidade, autonomia e outras questōes nas literaturas de Angola, Cabo Verde, Moçambique e S. Tomé e Príncipe, Porto, Ediçōes Afrontamento, 1992.

LÉONARD, Yves, “Salazarisme et Lusotropicalism, histoire d'une appropriation”, Lusotopie, 1997, pp. 211-226.

LOBO, Pedro de Sousa, "A Originalidade Humana de Cabo Verde", Claridade, no 9, São Vicente, Cabo Verde, Dezembro de 1960, pp. 64-69.

LOPES, Baltasar, "Notas para o estudo da linguagem das ilhas", Claridade, no 2, Sáo Vicente, Cabo Verde, Agosto, 1936, pp. 5 e 10.

LOPES, Baltasar, “Uma Experiência Românica Nos Trópicos I”, Claridade, no 4, São Vicente, Cabo Verde, Janeiro, 1947, pp. 15-22.

LOPES, Baltasar, "Uma Experiência Românica Nos Trópicos II”, Claridade, no 5, São Vicente, Cabo Verde, Setembro, 1947, pp. 1-10.

LOPES, Baltasar, "O Folclore Poético da Ilha de S. Tiago", Claridade, no 7, São Vicente, Cabo Verde, Dezembro, 1949, pp. 43-51.

LOPES, Baltasar, Cabo Verde Visto por Gilberto Freyre, Praia, Imprensa Nacional, 1956.

LOPES, João, "Apontamento", Claridade, no 1, São Vicente, Cabo Verde, Março de 1936, p. 9.

LOPES, Manuel, “Tomada de Vista”, Claridade, no 1, São Vicente, Cabo Verde, Março de 1936, pp. 5-6.

LOPES, Manuel, "Reflexôes Sobre a Literatura Cabo-Verdiana ou a Literatura nos Meios Pequenos", in Colóquios Cabo-Verdianos, Lisboa, Junta de Investigação do Ultramar, 1959, pp. 1-22.

LUCAS, Rémy, "Aventura e Rotina: Gilberto Freyre e L’Afrique”, Lusotopie, 1997, pp. $237-$ 245.

MARIANO, Gabriel, "Do Funco ao Sobrado ou o «Mundo» que o Mulato Criou”, in Colóquios Cabo-Verdianos, Lisboa, Junta de Investigação do Ultramar, 1959, pp. 23-49. 
MASSA, Jean-Michel, "Heurs et Malheurs de Gilberto Freyre en Guinée Portugaise et au CapVert”, Lusotopie, 1997, pp. 227-236.

MONTEIRO, Félix, "Bandeira da Ilha do Fogo - O Senhor e o Escravo Divertem-se", Claridade, no 8, São Vicente, Cabo Verde, Maio, 1958, pp. 9-22.

NETO, Sérgio, "Cabo-verdianidade e Luso-tropicalismo: Duas visões de Cabo Verde em tempos de Estado Novo", Estudos do Século XX, no 3, 2003, pp. 289-321.

NETO, Sérgio, Colónia Mártir, Colónia Modelo: Cabo Verde na Imprensa Ultramarina Portuguesa (1925-1965), Dissertação de Mestrado em História Contemporânea, apresentada à Faculdade de Letras da Universidade de Coimbra, sob a orientação do Prof. Doutor Luís Reis Torgal, Coimbra, Faculdade de Letras, 2007.

OLIVEIRA, Osório de, "Palavras sobre Cabo Verde para serem lidas no Brasil", Claridade, nº2, São Vicente, Cabo Verde, Agosto, 1936, p. 4.

OLIVEIRA, Osório de, "A Literatura Cabo-Verdiana é uma realidade", Cabo Verde - Boletim de Propaganda e Informação, no 27, Praia, Dezembro, 1951, pp. 29-30.

OLIVEIRA, Mário António F., Reler África, Coimbra, Instituto de Antropologia, Universidade de Coimbra, 1990.

PEIXEIRA, Luís Manuel de Sousa, Da Mestiçagem à Caboverdianidade: Registo de uma Sociocultura, Lisboa, Ediçôes Colibri, 2003.

RIBEIRO, Margarida Calafate, Uma História de Regressos: Império, Guerra e Pós-colonialismo, Porto, Ediçôes Afrontamento, 2004.

ROCHETEAU, Guilherme, "Presença de Gilberto Freyre", Cabo Verde - Boletim de Propaganda e Informação, no 26, Praia, Novembro, 1951, p. 16.

ROMANO, Luís, "O Caso Caboverdeano na Moderna Literatura”, Vértice, vol.XIV-131-132, Agosto/Setembro, 1954, pp. 485-489.

SILVEIRA, Onésimo, Consciencialização na Literatura Caboverdiana, Lisboa, Edição da Casa dos Estudantes do Império, 1963.

SOUSA, Teixeira de, "Uma visita desejada", Cabo Verde - Boletim de Propaganda e Informação, $n^{\circ} 27$, Praia, Dezembro, 1951, pp. 31-32.

SILVESTRE, Osvaldo, "A Aventura Crioula Revisitada: Versôes do Atlântico Negro em Gilberto Freyre, Baltasar Lopes e Manuel Ferreira”, in ACT 6 - Literatura e Viagens Pós-coloniais, (org.) Helena Carvalhão Buescu e Manuela Ribeiro Sanches, Lisboa, Ediçôes Colibri, pp. 63-103.

SMITH, Anthony D., A Identidade Nacional, 1a ediçāo, Lisboa, Gradiva, 1997.

TORGAL, Luís Reis, "Muitas Raças, Uma Nação ou o mito de Portugal multirracial na «Europa» do Estado Novo", Estudos do Século XX, no 2, Coimbra, Edição CEIS 20, Quarteto Editora, 2002.

VENÂNCIO, José Carlos, Colonialismo, Antropologia e Lusofonias: Repensando a presença portuguesa nos trópicos, Lisboa, Vega, 1996. 


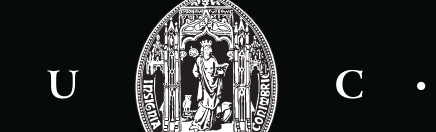

